\title{
Augmented Reality for Pipe Thread Connection Type Training
}

\author{
Ravi Ardi Wiyantoko ${ }^{1}$, Ahmad Hamim Thohari², Muhammad Dzuhri Maarief ${ }^{3}$ \\ * Informatics Engineering, Batam State Polytechnic \\ ** Multimedia and Network Engineering, Batam State Polytechnic \\ wiyantokoravi@gmail.com ${ }^{1}, \underline{\text { hamim@ @olibatam.ac.id }}$
}

\begin{tabular}{l} 
Article Info \\
\hline Article history: \\
Received July $14^{\text {th }}, 2020$ \\
Revised July $22^{\text {th }}, 2020$ \\
Accepted July $27^{\text {th }}, 2020$ \\
\hline
\end{tabular}

Keyword:

Training

Threads

Augmented Reality

\begin{abstract}
The process of extracting oil and gas is carried out by drilling with a depth of more than 200 meters below the surface of the ground, so one steel pipe is needed to run the process. The manufacture of steel pipes for the opening process has special standards, one of which is a long pipe. To reach a depth of 200 meters below the ground level, a pipe connection is needed to reach that height. The method of connecting the pipes is called the Thread Connection Type. This method has more than 20 types of threads to be applied in pipe joints. To facilitate the discussion of the types of threads and their specifications, we need a technology that can be used interactive and mobile learning media to deliver detailed information on the type of thread. The author uses the use of Augmented Reality (AR) technology to be applied as an Android-based training media that can facilitate the existing Connection Thread along with special specifications with 3D visualization. This study aims to measure the validity and practicality of using ISO 25010 (in terms of functional suitability, performance efficiency, portability and usability) of learning media so that it is easier to understand and practical. The study consisted of two parts: 1) Validity by experts (5 experts), 2) Practicality by trainees or employees (16 participants) using the USE Questionnaire instrument. Furthermore, in application development using the Multimedia Development Life Cycle (MDLC) method as its development method. As a result, the application was declared feasible with the results of the percentage of experts Validity of $96 \%$ and Practicality by employees of $79 \%$.
\end{abstract}

\section{INTRODUCTION}

As can be trusted that we will never be separated from oil and gas. Judging from the video documentary of Chesapeake Energy, the process of extracting oil and gas is carried out by drilling a height of more than 200 meters below the surface of the land, this process is called oil and gas exploration [1]. The exploration process has a very large risk and also requires special supporting tools such as steel pipes, special drill bits, etc. These tools are known as OCTG (State Oil Tubular Goods). The manufacture of steel pipes has special standards, one of which is the length of the pipe. To reach a depth of 200 meters underground requires a method of connecting pipes called Thread Connection Types. This method requires special training to determine its form and specifications.

One of the training that has been carried out is the Debt Inspection Training or the introduction of connection types. This training requires employees to discuss every detail of the product taken. The issue issued is the number of threads that must be controlled by each employee not just one, more than 20 types of threads. Seeing such conditions deactivate the training that has been done well, the writer needs to need those who want to be better, where for this type of discussion thread employees need to facilitate the system for this type of thread, this system can be used wherever and whenever needed for space training. The author agrees to use AR technology to be applied as an Android-based training media that can adjust thread connections that are looking for specifications. Through a long process, the authors worked closely with the Training Center to create a learning media using an Android-based AR technology called CARON (Citra Augmented Reality For Education). CARON is an application that can display Connection Thread in 3-dimensional form for specifications. 


\section{RESEARCH METHOD}

This research is a type of research and development or Research and Development (R\&D). Research and development are research methods used to produce certain products, and test the effectiveness of these products [2]. Research and development is a research approach to produce new products or improve existing products [3]. Then, to build an application that is used to identify the type of pipe thread connection, a development method is needed, in this study the method used by the author to build a CARON (Image Augmented Reality For Education) application is Multimedia Development Life Cycle (MDLC). This method has six stages, namely concept, design, material collecting, assembly, testing, and distribution.

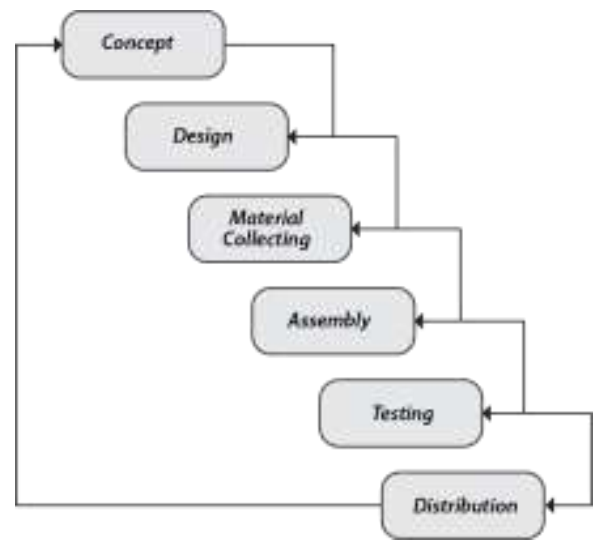

Figure 1. Multimedia Development Life Cycle (MDLC) Methods

These six stages do not have to be sequential in practice, they can exchange positions. Even so, the concept stage must indeed be the first thing done [4]. Following are the steps carried out in this study:

1. Concept, determine the purpose of making the application and the user of the application. In this study, the purpose of the application is to help trainees recognize thread connections using Augmented Reality technology on Android in the form of 3D.

2. Design, aims to make detailed specifications about the project architecture, the appearance and project material requirements, as well as style. This stage uses the user interface design.

3. Material Collecting, the stage of collecting materials according to needs. These materials include images, product data, 3D objects. These materials were obtained through discussions with the company's training center.

4. Assembly, the overall stage of making multimedia material, the application is based on the concept and design stage. This stage is created using the Unity application.

5. Testing, carried out to ensure that the results of making an application in accordance with the plan [5]. There are two types of testing used, namely Alpha Testing and Beta Testing. Alpha testing is testing conducted by the manufacturer or the manufacturer's own environment. Both tests are carried out using ISO 25010, ISO 25010 is part of software product quality requirements and evaluation (SQuaRE), used to see the quality of a software used by companies, agencies, and organizations [6]. The four aspects of ISO 25010 used are:

a. Functional Suitability, testing the application level can provide the required functionality.

b. Performance Efficiency, testing the application level provides the right performance as needed.

c. Portability, tests the level of effectiveness and efficiency of the application when used fromone device to another.

d. Usability, testing the application level can be used by users to achieve certain goals effectively, efficiently and meet satisfaction in their use.

6. Distribution, distribution is the final stage after the application is declared eligible to use. At this stage the application will be given to the company's training center in a storage such as hard drives, or mobile devices. 


\section{RESULTS AND ANALYSIS}

In this section, it is explained the results of research and at the same time is giventhe comprehensive discussion. Results can be presented in figures, graphs, tables and others that make the reader understand easily [2], [5]. The discussion can be made in several sub-chapters.

\subsection{Concept}

At the concept design stage, the authors analyze the needs of the problems that occur, the results are presented in Table 1.

Tabel 1: Analisis Permasalahan

\begin{tabular}{ccc}
\hline Prosedur Berjalan & Permasalahan & Kebutuhan \\
\hline $\begin{array}{c}\text { Media pelatihan menggunakan } \\
\text { buku dan slide presentasi }\end{array}$ & $\begin{array}{c}\text { Jumlah buku terbatas, } \\
\text { kurangnya mobilitas }\end{array}$ & $\begin{array}{c}\text { Dibutuhkan sistem yang efektif, } \\
\text { praktis dan lengkap }\end{array}$ \\
\hline $\begin{array}{c}\text { Pelatihan dilakukan di ruangan } \\
\text { Training dan tatap muka }\end{array}$ & $\begin{array}{c}\text { Untuk mendapatkan pelatihan, } \\
\text { karyawan harus mengatur } \\
\text { jadwal dengan pihak Training } \\
\text { Center }\end{array}$ & $\begin{array}{c}\text { Pelatihan bisa dilakukan dimanan } \\
\text { dan kapanpun }\end{array}$ \\
\hline $\begin{array}{c}\text { Penggunaan Material asli, } \\
\text { Gambar 2D sebagai media } \\
\text { visualisasi }\end{array}$ & Kurang interaktif, dan berat & $\begin{array}{c}\text { Dibutuhkan visualisasi 3D yang } \\
\text { interaktif }\end{array}$ \\
\hline
\end{tabular}

Based on the existing problems, the authors discuss with the company's training center to create an application that can facilitate employees in the process of introducing the Thread Connection training. The following in Table 2 below is the application concept for meeting the needs of Thread Inspection Training:

\begin{tabular}{cc}
\hline Concept & Explanation \\
\hline Teknologi & Augmented reality menggunakan metode User Defined Target/ Markerless \\
\hline Platform & Android \\
Tujuan & $\begin{array}{r}\text { Membangun aplikasi augmented reality secara tepat, interaktif dan efektif } \\
\text { sebagai media media pelatihan pengenalan tipe koneksi pipa. }\end{array}$ \\
\hline Sasaran & Trainer, Karyawan / Peserta Pelatihan \\
\hline Visualisasi & Objek 3D \\
\hline
\end{tabular}

Based on the application concepts that have been described, the following is a simple description of the application flow design:

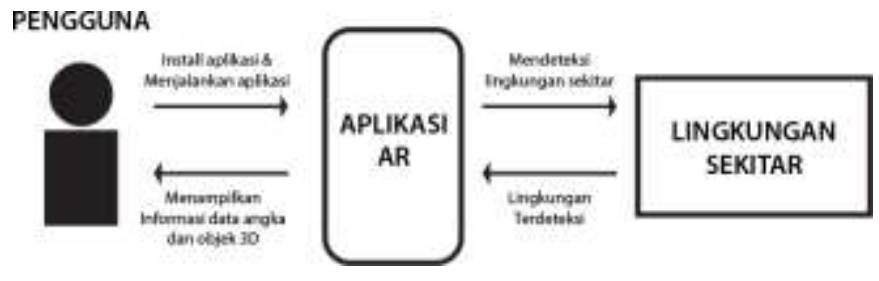

Figure 2. Application Design 
The application is run by the user by installing the application on the smartphone, running the application, then the application detects the surrounding environment, if the state of the environment is relevant then the $\mathrm{AR}$ is run by displaying information on numbers and $3 \mathrm{D}$ objects, otherwise the system detects the surrounding environment again.

\subsection{Design}

Following is the CARON application user interface design:

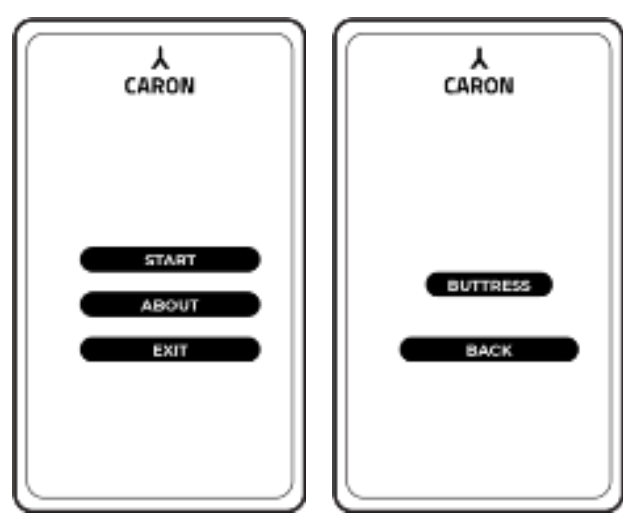

Figure 3. Menu dan Menu Jenis Koneksi

In designing the user interface in the Main Menu there are 3 buttons, 1) Start button to run AR, 2) About button to display application overview information, 3) Exit Button to exit the application. If you select the Start Button, then the user will be directed to the display select the type of connection, there is a Buttress Button to run AR.

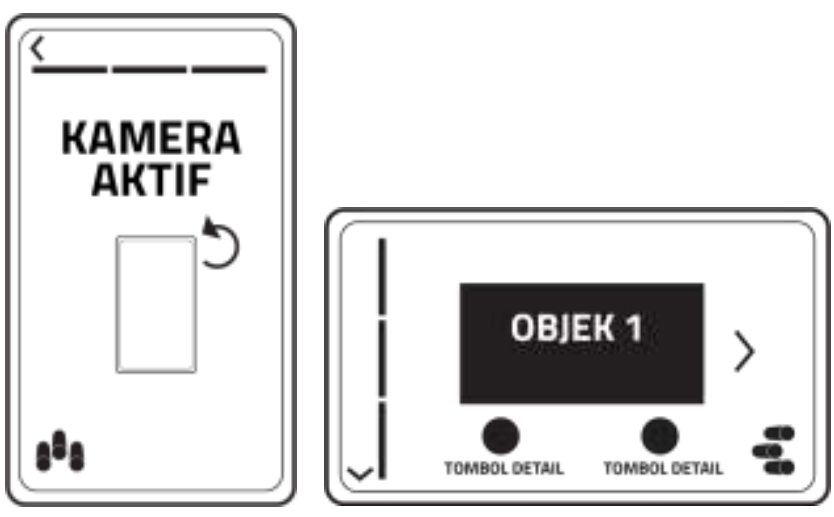

Figure 4. Display AR Running

When the Buttress button is pressed the AR camera will be active, then the user presses the pipe icon button to bring up the object, the object that appears is accompanied by a detail button to display the thread shape. 


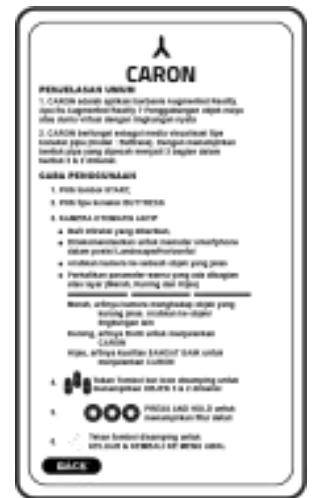

Figure 5. Display About

The About button functions to display an explanation of the application and how to use the application, as shown in Figure 5.

\subsection{Material}

Materials or materials needed for CARON applications are images, product data and 3D objects. These materials are built using the Autodesk 3Ds application and then exported and combined in a unity application based on the previous design stages. The following product drawings are presented in Table 3:

Tabel 3: Product Drawing

\begin{tabular}{l}
\hline Keterangan \\
\hline $\begin{array}{c}\text { Original Product } \\
\text { Buttress } \\
\text { Connection }\end{array}$ \\
3D Buttress \\
Connection \\
Model 1 \\
3D Buttress \\
Connection \\
Model 2 \\
3D Buttress \\
Connection \\
Model 3 \\
\hline 3D Buttress \\
Connection \\
Model 4
\end{tabular}

\subsection{Assembly}

In the assembly phase aims to make products from materials that have been collected based on the concepts that have been designed. In this stage it is divided into several parts, namely creating 3D objects, creating user interfaces, implementing 3D objects into AR, and rendering. The initial stage is to create a 3D pipe object, this stage is created in the Autodesk 3Ds application based on the original product image. After the original product is visualized as a 3D object as shown in Figure 6, the object is exported in .max format. 


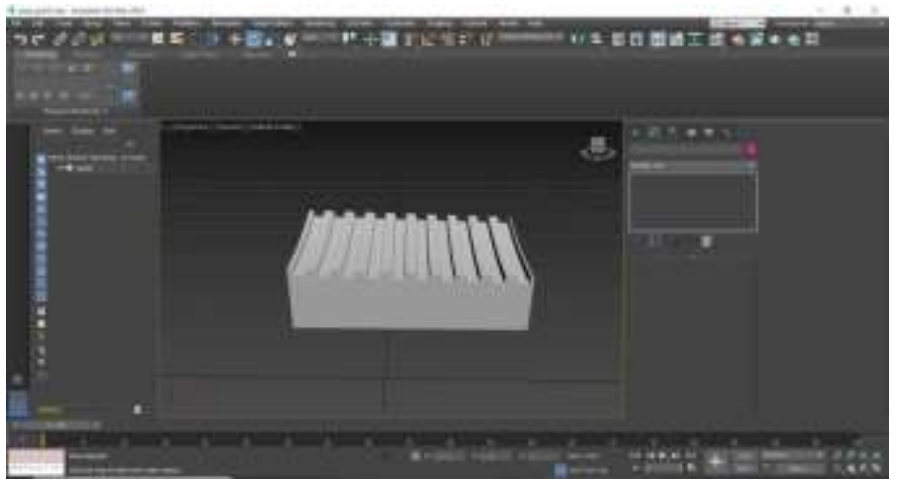

Figure 6: Making 3D Objects in Autodesk 3Ds

Next, the steps to create a user interface, namely designing the appearance of the application that will be used by the user, ensuring that each button functions and matches the flow of the application. The results of the steps to create a user interface are shown in Figure 7.

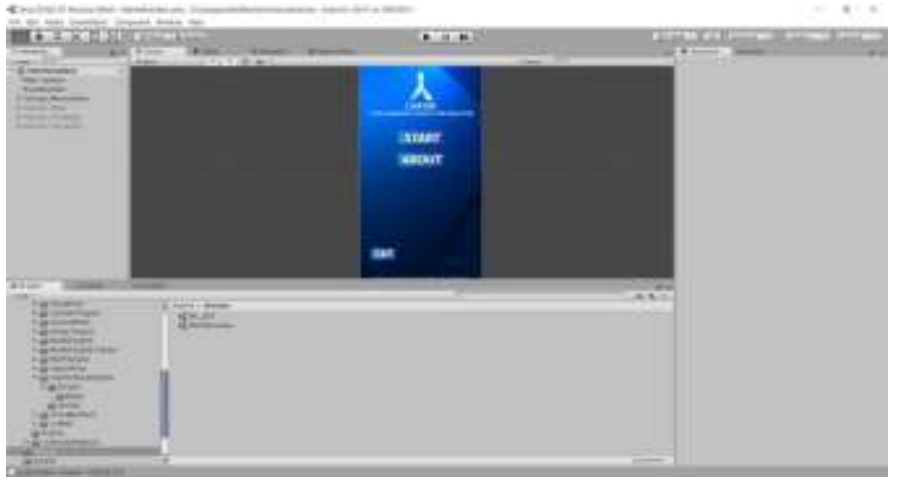

Figure 7: Making User Interface

Furthermore, the stages of the implementation of $3 \mathrm{D}$ objects, this process is carried out in the AR scene by placing $3 \mathrm{D}$ objects into the AR camera, the goal is when AR is run the $3 \mathrm{D}$ object which will be displayed as shown in Figure 8.

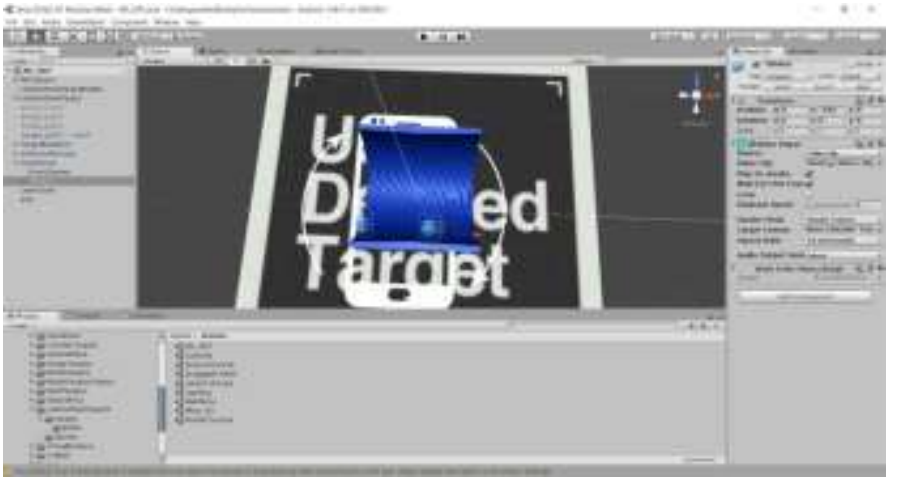

Figure 8: Implementation of 3D Objects

Then the rendering process is done, rendering is the process of combining the scenes that have been made, the user interface with AR, the goal is to become an application that can be run on Android, with the .apk format. The rendering process is shown in Figure 9. 


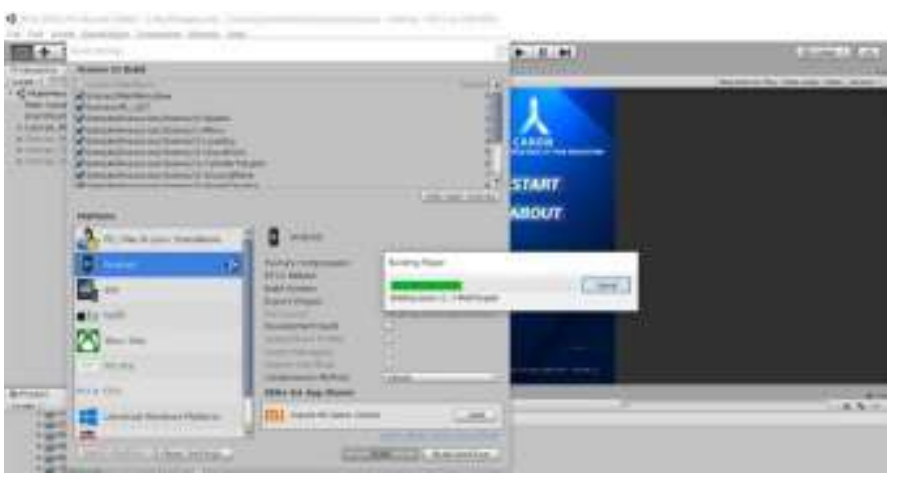

Figure 9: Rendering

After the rendering process is complete, the application with the .apk format can continue to the installation process on an Android device.

\subsection{Testing}

\subsubsection{Functional Suitability}

Application level testing can provide the functionality needed. At this stage of testing, checking the application works in accordance with its functionality in the company. This test was conducted at PT Citra Tubindo Tbk, one of the companies engaged in pipe processing. There are several stages carried out in this test, namely the application demo directly by the examiner to ensure each function runs well, then conducts material validation testing aimed at ensuring the validity of the material displayed on the application, whether the application meets or meets the learning standards or not. Following is the appearance of the application while it is running, presented in Table 4:

\begin{tabular}{c} 
Keterangan \\
\hline $\begin{array}{c}\text { Tampilan main menu dan pilih jenis } \\
\text { koneksi saat aplikasi dijalankan, pada } \\
\text { bagian main menu terdapat 3 tombol, yaitu } \\
\text { start, about dan exit. Kemudian pada } \\
\text { bagian pilih jenis koneksi terdapat } 2 \\
\text { tombol yaitu Buttres untuk menjalankan } \\
\text { AR dan tombol kembali }\end{array}$
\end{tabular}




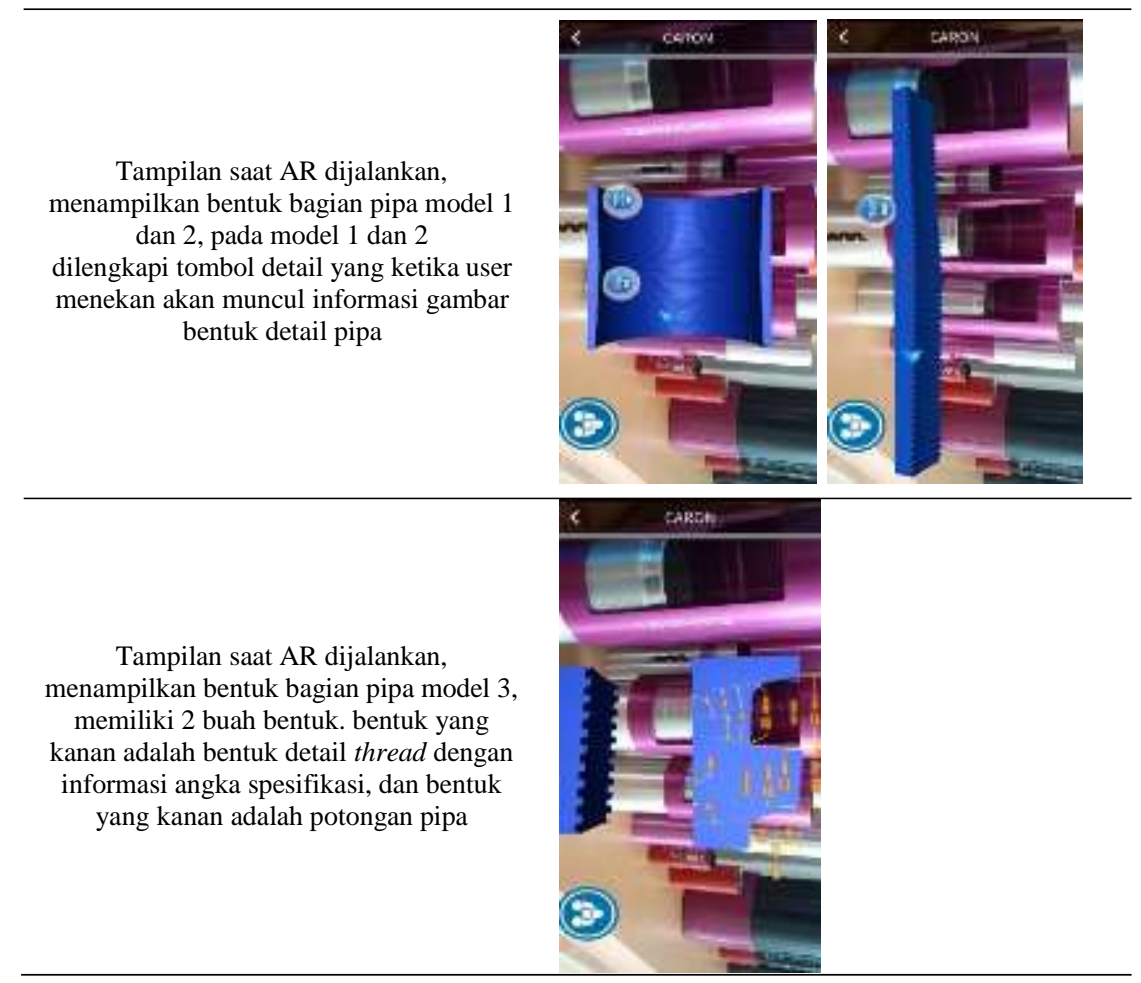

This test is carried out by 5 experts, namely: 1) Training Specialist, in charge of providing training to employees, 2) IT Manager, who is responsible for the processing and maintenance of information technology in the company, 3) IT Programmers, building systems for company needs, 4 ) IT Programmer Analyst, responsible for preparing the needs in the system design process, and 5) IT HR Programmer, responsible for the system requirements in the HR division. The following indicators are tested:.

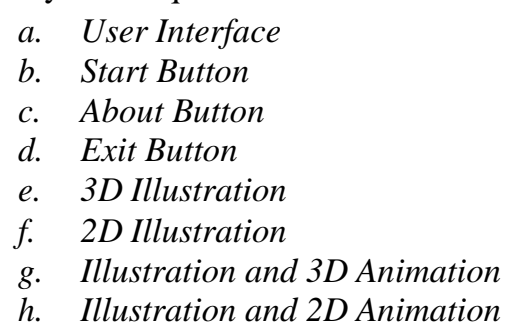

Testing is carried out directly application experiments, after that followed by filling out the questionnaire with each question having a maximum score of 40. The following test results are presented in Table 5.

Tabel 5: Functional Suitability

\begin{tabular}{ccc}
\hline Tester & Score & Percentage \% \\
\hline $\begin{array}{c}\text { Expert 1 } \\
\text { (Training Specialist at PT Citra Tubindo Tbk) }\end{array}$ & 40 & 100 \\
\hline $\begin{array}{c}\text { Expert 2 } \\
\text { (IT Programmer at PT Citra Tubindo Tbk) }\end{array}$ & 40 & 100 \\
\hline $\begin{array}{c}\text { Expert 3 } \\
\text { (IT Programmer Analyst at PT Citra Tubindo Tbk) }\end{array}$ & 40 \\
\hline $\begin{array}{c}\text { Expert 4 } \\
\text { (IT HR Programmer at PT Citra Tubindo Tbk) }\end{array}$ & 38 & 95 \\
\hline $\begin{array}{c}\text { Expert 5 } \\
\text { (IT Manager at PT Citra Tubindo Tbk) }\end{array}$ & 40 & 100 \\
\hline
\end{tabular}


The results of testing from the 5 experts got a percentage of $99 \%$, the following test results are presented in Figure 10 graph of functional suitability test results:

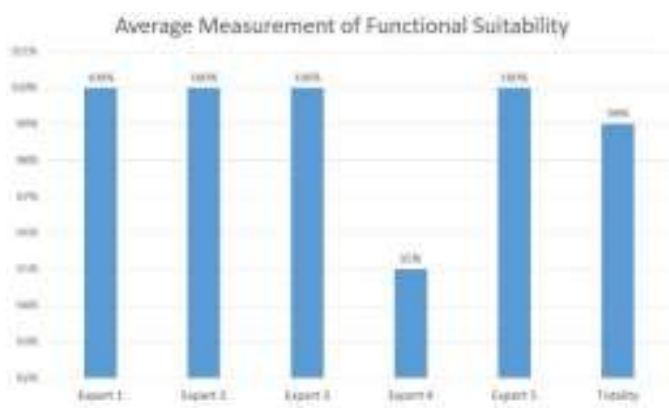

Figure 10: Average Measurement Functional Suitability Chart

In addition, testing is also carried out on the application content based on the Thread Connection Type learning module that aims to ensure the validity of the material displayed. The validation was conducted by Trainer Specialist at PT Citra Tubindo Tbk. The results of this test are presented in Table 6:

Table 6: Material Validation

\begin{tabular}{ccccc}
\hline Indicator & Trainer 1 & Trainer 2 & Score & Percentage \% \\
\hline $\begin{array}{c}\text { Pemodelan pipa dalam bentuk 3D } \\
\begin{array}{c}\text { Pemodelan pipa dalam bentuk 2D } \\
\text { (Facing, First Thread, Perfect Thread, } \\
\text { Cross Section) }\end{array}\end{array}$ - $^{\text {Crosi Detail Koneksi }}$ & 8 & 8 & 16 & 100 \\
\hline Total & 8 & 8 & 16 & 100 \\
\hline Informasi & 24 & 24 & 48 & 100 \\
\hline
\end{tabular}

The results of this test show that the material displayed is in accordance with the teaching material from the Thread Connection Type module, the percentage obtained is $100 \%$.

\subsubsection{Performance Efficiency}

Performance efficiency testing is done by the author with the Android Studio application, using the Profiler feature that produces tracing files with the .ctrace format and is displayed through the Perfetto website (ui.perfetto.dev), the results of these tests are presented in Figure 11:

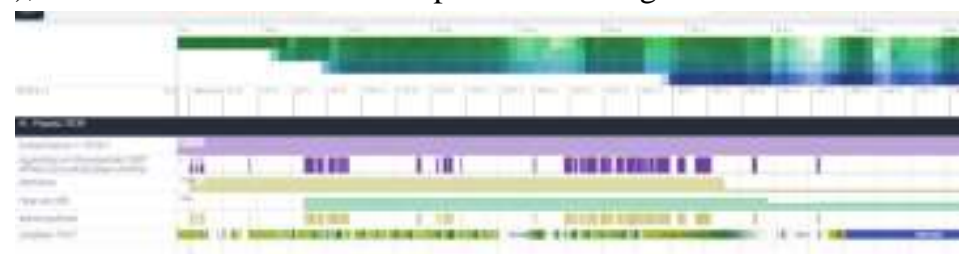

Figure 11: Performance Trace

Based on performance efficiency testing the results can be concluded as presented in Table 7 below:

Table 7: Performance Efficiency

\begin{tabular}{ll}
\hline Indicator & Average/Unit \\
\hline Time Behaviour & $43.6 \mathrm{~s}$ \\
\hline Resource Utilization on CPU & $5 \%$ \\
\hline Resource Utilization on Memory & $2,9 \mathrm{MB}$ \\
\hline
\end{tabular}


Tabel 8: Fluksi Cahaya

\begin{tabular}{ll}
\hline Parameter & Fluksi Cahaya (Ø) \\
\hline Low ( Red ) & $0-50$ \\
\hline Medium (Yellow) & $50-70$ \\
\hline Suitable (Green) & $>70$ \\
\hline & \\
\hline & \\
\hline & \\
\hline & CARON \\
\hline
\end{tabular}

Figure 12: Color Parameter

The color parameter serves as a benchmark in the application to report the relevance of the surrounding environment that is the area of the AR to run, the red color indicates that the environment is not good enough to run AR, the yellow color indicates the area is good enough to run AR, and the green color indicates a good area to run AR in terms of light sources that affect the quality of the camera taking pictures of the environment that will be used as an area.

\subsubsection{Portability}

The aspects of portability testing are testing of adaptability, installability, and replaceability. This test is carried out by the author by involving the development environment. Aspect of adaptability and installability testing is done by experimenting to install, run, and uninstall applications on various OS versions and screen sizes. While the replaceability aspect is carried out by experimenting to install new versions or update applications on various types of devices. The following are presented in Table 9 on the results of various devices for portability:

Table 9: Adaptability, Installability \& Replaceability

\begin{tabular}{lll}
\hline Device Type & OS Version & Result \\
\hline Samsung J4+ & 9.0 & Complete \\
\hline Advan & 8.0 & Complete \\
\hline Xiaomi Note 5A & 7.1 .2 & Complete \\
\hline $\begin{array}{l}\text { Sony Xperia XZ } \\
\text { Premium }\end{array}$ & 7.1 & Complete \\
\hline Vivo S1 & 9.0 & Complete \\
\hline
\end{tabular}

As a result the application can run well on various testing devices.

\subsubsection{Usability}

Usability testing is included in the beta test, namely testing by testing the results of the application directly to the user and calculating the assessment results based on the questionnaire that has been filled. This test involved 16 users directly, carried out at PT Citra Tubindo Tbk. The following are presented in Table 10 characteristic respondents:

Table 10: Responden Characteristic Table

\begin{tabular}{lllll}
\hline \multicolumn{1}{c}{ Profile } & \multicolumn{1}{c}{ Description } & Total & \% \\
\hline \multirow{2}{*}{ Educations } & SMA/SMK & & $\underline{12}$ & $\underline{75}$ \\
\cline { 2 - 3 } & D3/S1 & $\underline{4}$ & $\underline{\mathbf{2 5}}$ \\
\cline { 2 - 3 } & Total & $\underline{160}$
\end{tabular}




\begin{tabular}{llcc}
\hline \multirow{3}{*}{ Gender } & Male & 14 & 88 \\
\cline { 2 - 4 } & Female & 2 & 13 \\
\cline { 2 - 4 } Total & $\mathbf{1 6}$ & 100 \\
\hline \multirow{3}{*}{ Age } & $17-25$ Years & 11 & 69 \\
\cline { 2 - 4 } & $26-35$ Years & 5 & 31 \\
\cline { 2 - 4 } Experience & Total & $\mathbf{1 6}$ & 100 \\
\cline { 2 - 4 } & $<2$ Years & 0 & 0 \\
\cline { 2 - 4 } & $2-5$ Years & 12 & 75 \\
\cline { 2 - 4 } & $>5$ Years & $\mathbf{1 6}$ & 100 \\
\cline { 2 - 4 } & Total & &
\end{tabular}

Furthermore, usability testing was conducted on a number of respondents. Testing is done using the USE Questionnaire, USE Questionnaire is a user satisfaction assessment technique besides SUS, SUMI, and QUIZ used for computer science that is developed with general questions for all users [7]. The following is presented in Figure 13, the usability test results graph:

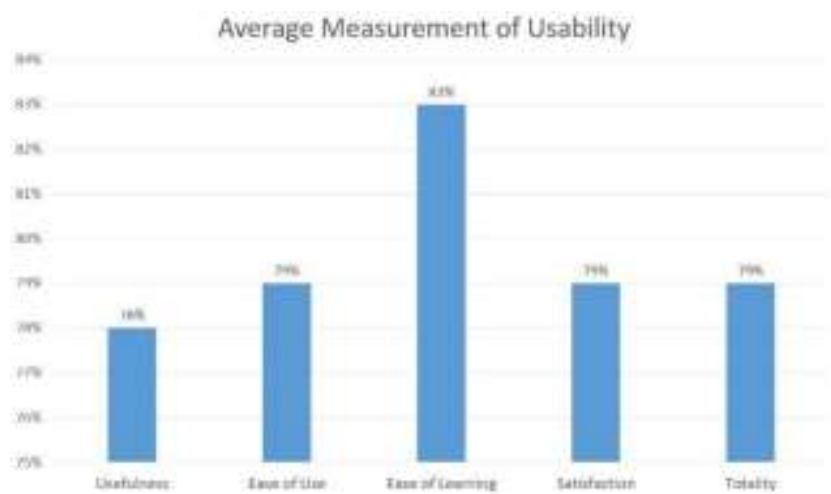

Figure 13: Average Measurement Usability Chart

The result is that in the aspect of usefulness get a percentage of 78\%, ease of use 79\%, ease of learning $83 \%$, and satisfaction $79 \%$, with an average result of a percentage of $79 \%$ the application is declared feasible.

\subsection{Distribution}

Based on the results of the analysis and declared feasible to use the application can be distributed to the Training Center as a learning media for Thread Connection Type training. The distribution is done by moving the application master file into online and offline storage at the Training Center.

\section{CONCLUSION (10 PT)}

This research is based on the problems encountered at the Training Center, regarding the training that has been carried out, one type of training is Thread Inspection Training, in this training employees are required to master more than 20 types of threads. Then a system was built to identify thread types precisely, interactively and effectively. The application is CARON (Image Augmented Reality for Education), this android-based system that can display Thread Connection in 3D.

This application has been tested for ISO 25010 standards with 4 aspects, namely: 1) Functional Suitability, tested by 5 Experts with a percentage of $99 \%$ that is very feasible, and the material contained in accordance with the learning standards validated by the instructor. 2) Performance Efficiency, declared feasible with details of $43.6 \mathrm{~s} /$ thread time behavior, average memory usage of $2.9 \mathrm{MB}$, and average CPU usage of $5 \% .3$ ) Portability, is declared feasible and runs well on the testing device. 4) Usability, is declared feasible with the results of a percentage of $79 \%$ with the number of respondents 16 people using the USE Questionnaire instrument. Based on the conclusions and research the authors provide suggestions for further development of a database that can be accessed online with additional types of Thread Connection added. 


\section{REFERENCES}

[1] Chesapeake Energy Horizontal Drilling Method. [Film]. U.S: Chesapeake, 2012.

[2] Sugiyono, Metode Penelitian Kuantitatif Kualitatif dan R\&D, Bandung: Alfabeta, 2012.

[3] N. Syaodiah and Sukmadinata, Metode Penelitian Pendidikan, Bandung: Alfabeta, 2009.

[4] R. A. Rahman and D. Tresnawati, "Pengembangan Game Edukasi Pengenalan Nama Hewan Dan Habitatnya Dalam 3 Bahasa Sebagai Media Pembelajaran Berbasis Multimedia," Algoritma, vol. 13, no. 1, p. 7, 2016., in press.

[5] S. Nurajizah, "Implementasi Multimedia Development Life Cycle Pada Aplikasi Pengenalan Lagu Anak - Anak Berbasis Multimedia," PROSISKO, vol. III, no. 1, p. 2, 2016., in press.

[6] I. Alfian, "Analisis Kualitas Sistem Aplikasi M-Library di Perpustakaan Universitas Gadjah Mada," PhD Thesis, vol. I, no. 1, p. 6, 2017., in press.

[7] A. M. Lund, "Measuring Usability with the USE Questionnaire," STC Community, 2001. [Online]. Available: http://www.stcsig.org. [Accessed 1 July 2020]. 